\title{
ジオテキスタイルを用いた盛土内の土畩浄化に 関する基礎的研究
}

\author{
今野雄太 $1 \cdot$ 峯岸邦夫 $2 \cdot$ 巻内勝彦 3
}

\begin{abstract}
近年，建設工事による産業廃棄物としての污染土が増加し，それに伴い対策工法も多様化している。 そこで, 本来廃棄処理する建設発生土を盛土材等の建設材料に転用するために行う土壌浄化改良工法として, ジオテキスタイルをドレーン材として使用し，その浄化効果を排水補強効果とともに評価・検討した。

本研究では，試料土に関東ロームと東金産山砂，川砂を使用し，污染土とジオドレーン材による室内土槽モ テル試験を行い, 粒径, 上載荷重, ドレーン材の敷設枚数, 敷設条件, 試料土の種類, 污染物質の種類, 水頭 等の諸条件を変化させ，着実な効果予測，より高い污染除去能力を持つ，諸条件の組み合わせを見出すための 基礎的実験を行い考察した。
\end{abstract}

キーワード : ジオテキスタイル, ドレーン材, 土壌浄化

\section{1. 研究背景之目的}

建設工事による発生土は近年増加の一途をたどっ ており，その適切な有効利用が求められている。建 設発生土は建設リサイクル法により再利用すべき副 産物として指定されているが，有害物質が基準値以 上混入している污染土が，ここ数年発見が格段に増 加傾向を示していることで, その調査・対策工事も 同様の傾向を示している。しかし，現状では污染物 質の種類・形態による効果も様々であり, 污染の拡 大する過程・現状土の状態等が十分に理解されてい ないことがある ${ }^{1)}$ 。よって，既存の技術であっても 効率的な効果の予測や低コスト技術への改良が必要 がある。そこで, 污染土壌のリサイクル, 軟弱地盤 の補強と言った観点から，新たにジオテキスタイル をドレーン材として使用し，土壌内の余剩水ごと污 染物質を排出し土壌浄化を促す工法を検討してみた。 本研究では, 試料土に関東ロームと東金産山砂, 比 較として透水係数の良い川砂，ドレーン材として不 織布ジオテキスタイルを使用して, 污染土とジオド レーン材による室内土槽モデル試験を行い, 上載荷 重, 敷設枚数, 敷設条件, 試料土の種類, 污染物質 の種類, 水頭等の諸条件を変化させ, 効果予測や, より高い污染除去能力求める実験を行った。

\section{2. 試験方法}

試料土として高含水比火山灰質粘性土（関東ロー
ム）と東金産山砂，比較対象として透水性の良い川 砂を使用し，混入する污染物質として灯油を使用し た。ドレーン材にはスパンボンド不織布 $\mathrm{S}-300$ (公称厚さ $3.0 \mathrm{~mm}$, 目付け $300 \mathrm{~g} / \mathrm{m}^{2}$ ) を用いた。試 験方法としては写真 - 1 に示す試験モデル土槽（内 寸法 $40 \mathrm{~cm} \times 55 \mathrm{~cm} \times 25 \mathrm{~cm}$ ）にドレーン材を水平敷設 し, 土槽上部から継続的に水を $700 \mathrm{~cm}^{3} / \mathrm{min}$ で流入 させ, 給水水位を一定に保った。そして排水量がほ ぼ安定した後に土とドレーン材の複合体として図ー 1 に示すように面内方向通水 - 排出量と垂直方向透 水・排出量の測定試験を行った。

以下に本研究の試験項目および条件を示す。

（1）関東ロームは自然含水比（ $\left.w_{n}=110 \%\right)$ 状態で 湿潤密度 $\rho_{\mathrm{t}}$ を $0.9 \mathrm{~g} / \mathrm{cm}^{3}$ になるように, 山砂は湿 潤密度 $\rho_{\mathrm{t}}$ を $1.4 \mathrm{~g} / \mathrm{cm}^{3}$ になるように所定の締固め エネルギーで土壌を均一に 8 分割して締め固める。 川砂は絶乾状態で相対密度 Dr $50 \%$ になるよう 同様に締め固めた。污染物質は, その各首ごとに 流入させた。また, 流入量は乾燥状態の試料土質 量に対して $2 \%$ とした。

（2）載荷重を $0 ， 5 ， 10 ， 15 ， 20 \mathrm{kPa}$ の 5 段階の 条件で試験を行ない, 土被り圧の影響を調べた。

（3） ジオテキスタイルを図- 2 , 図ー 3 のように 中央 3 枚, 分割 3 層敷設して, この条件による排 水・排出量と, 写真一 2 に示すオイルシートを用 いて測定する。污染物質排出量は，オイルシート の油分のみを吸収する特性を利用して, 排水量を 測定した後にそれを靦汼して表面上に浮かび上が る油分を測定する。オイルシートの質量を除いた

1学生会員, 日本大学大学院理工学研究科社会交通工学専攻, 博士前期課程（广274-8501 船橋市習志野台7-24-1） 2個人会員, 日本大学理工学部社会交通工学科, 助手 (同上) 3個人会員, 日本大学理工学部社会交通工学科, 教授（同上） 
ものを污染物質排出量として，その違いを比較検 討した。

（4）排水試験によって得られた面内方向通水量と 垂直方向透水量の割合および排水性能比を調べた。

（5）試験終了後に検知管を用いたガス吸引試験を 行い, ベンゼン・石油ナフサの残留濃度を調べた。

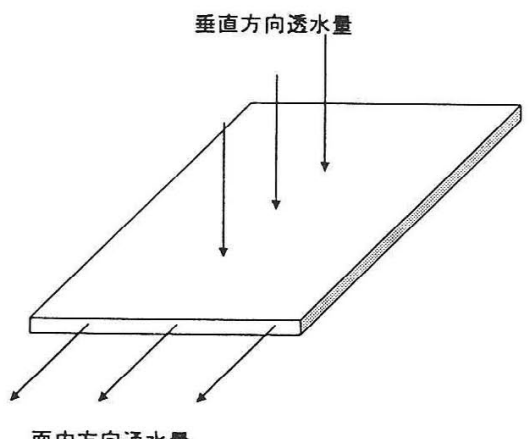

面内方向通水量

図-1 面内方向通水量・垂直方向透水量

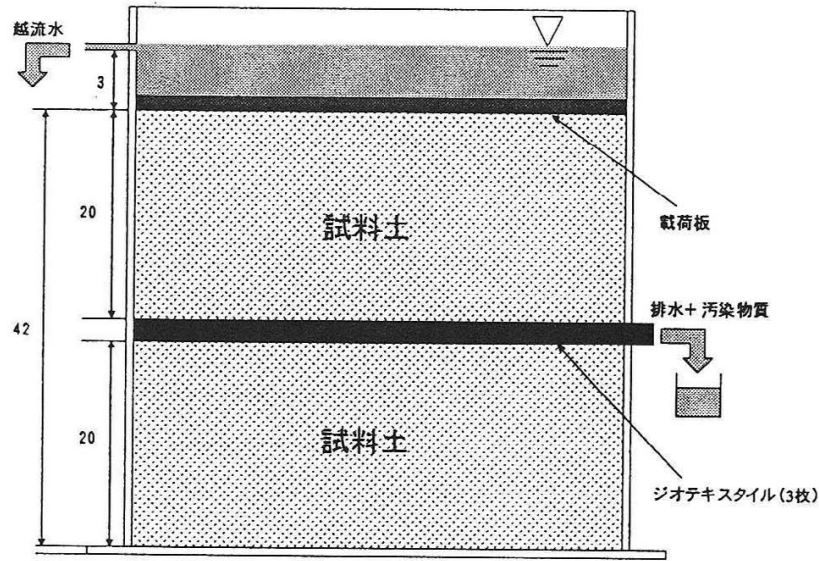

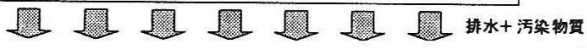

図 -2 中央 3 枚敷設図

单位: $\mathrm{mm}$

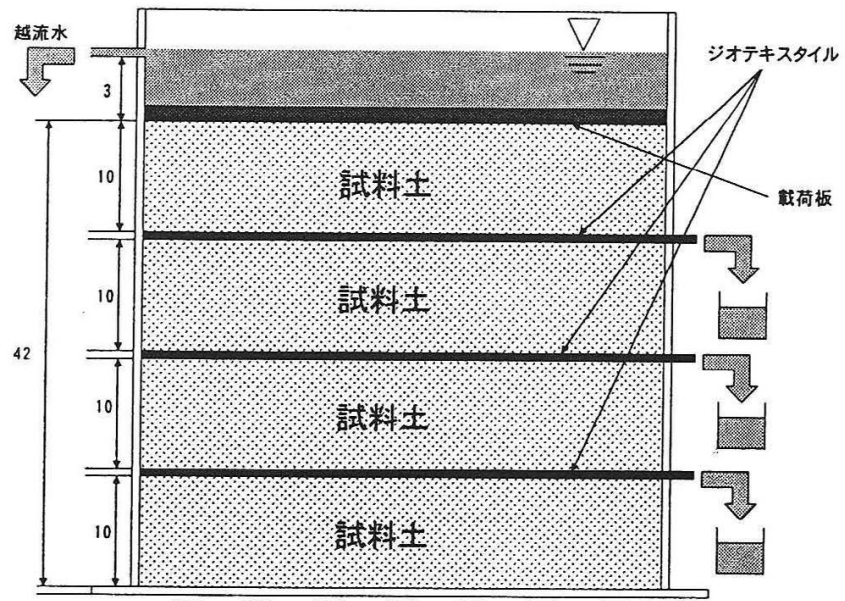

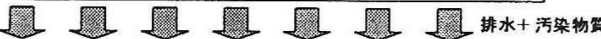

図 -3 分割 3 枚敷設図

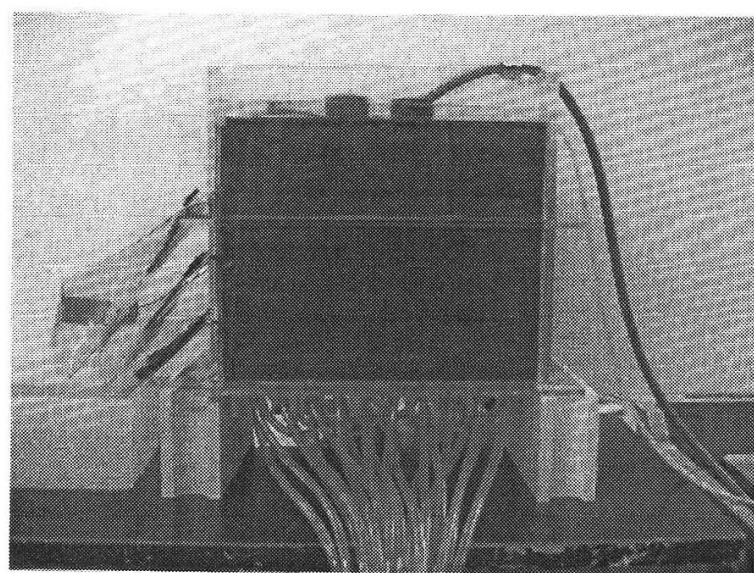

写真 -1 中央 3 枚敷設図

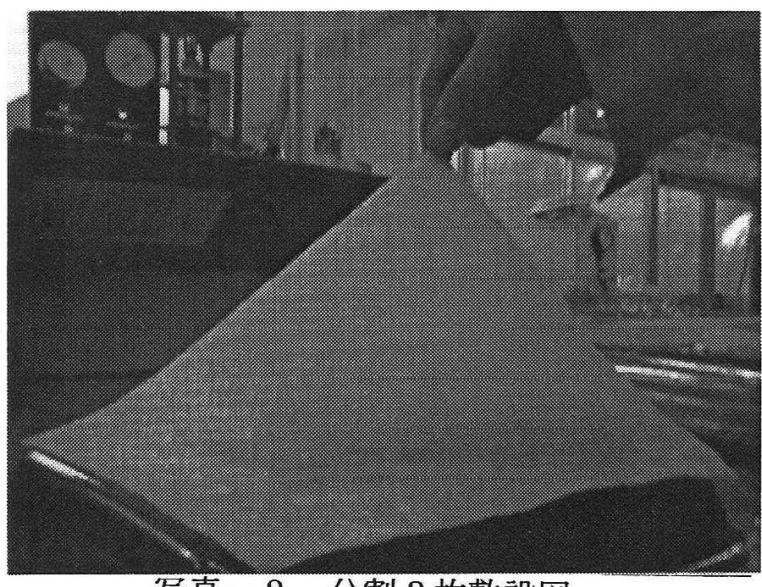

写真 -2 分割 3 枚敷設図

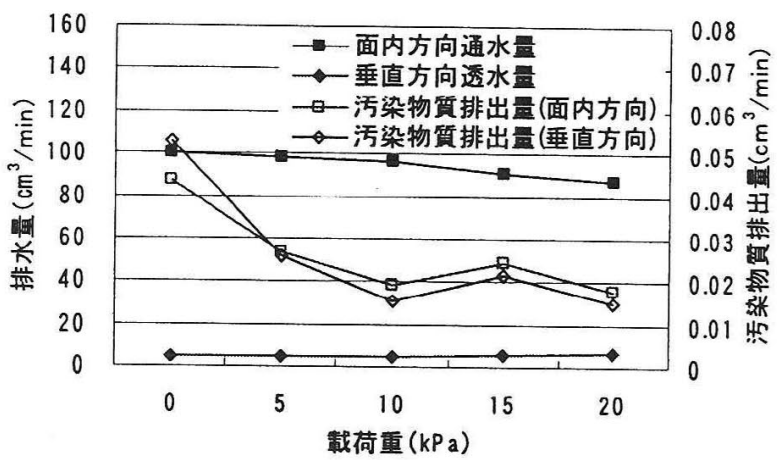

図－3 東金産山砂における排水・排出量と 載荷重に関する関係（中央 3 枚）

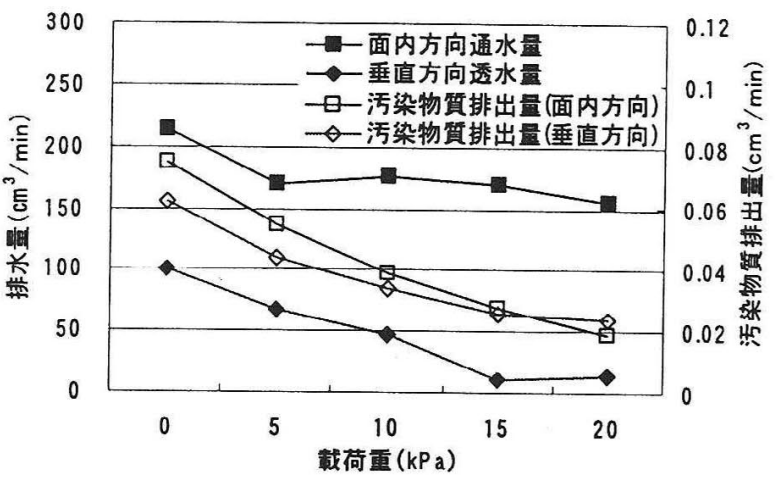

図-4川砂における排水・排出量之 載荷重に関する関係（中央 3 枚） 


\section{3. 室内試験結果と考察}

図-3〜図- 8 は, 試料土別に排水（通水・透水 量）・污染物質排出量と載荷重の関係を示したもの で, 図-3〜図- 5 は中央に 3 枚重ねて敷設した条 件, 図-6〜図-8は, 分割して 3 枚敷設した条件 である。載荷重が $5 \mathrm{kPa}, 10 \mathrm{kPa}, 15 \mathrm{kPa}, 20 \mathrm{kPa}$ と増 加するにつれて排水量・污染物質排出量が減少して いくのがわかる。これは，関東ローム，東金産山砂 においては, 載荷重が増加するにつれて土の密実化 が進み透水係数が低下, ドレーン材の排水断面積の 減少，目詰まりによる排水材の透水係数の低下とい ったことが挙げられる。川砂においても，排水量が 大きく減少するという結果になった。これには, ド レーン材や試料土の圧密作用による透水係数の低下 は若干作用するものの, ジオテキスタイルの表面に 油膜のような物を作ることによって排水材の透水係 数がここまで低下したと考えられる。また図ー 5 よ り載荷重が $0 \mathrm{kPa}$ のとき, 垂直方向のほうが污染物 質排出量の値が大きかったのは関東ロームが載荷重 を增加することによりドレーン材から污染物質を押 し出したと考えられる。

川砂と関東ロームでは排出量の減少率が異なり, 川砂で約 $70 \%$, 関東ローム $20 \%$ の減少であった。 関東ロームは, 吸着作用によりあらかじめ排出され る污染物質の量が制限される。よって, 排出される 油分が少量であったことから, 油による目詰まりが 発生しその分低減されたと考えられる。

試験前は, 載荷重を段階的に増加させるにつれて, 灯油が排水とともに排出されると予想した。しかし， 川砂・東金産山砂においては, 若干の污染物質排出 量の増加が見られたが，すぐに減少し安定していっ た。関東ロームにおいては, 增加傾向は殆どみられ ず，無載荷の段階からわずかの量しか排出されなか った。原因として粘性土特有の性質である吸着作用 が挙げられる。関東ロームに代表される粘性土を構 成する粘土鉱物は，マイナスの電荷を帯びているこ とが一般的であるので, 粘性土の表面は陰イオンに 荷電しており, 陽イオンを吸着する性質を持ってい る 2)。本実験で使用した石油系化学物質は, 複数の 有機物を含む ${ }^{3)}$ た，水に溶け出した陽イオンが土 垬に吸着するものと考えられる。図一 9 は, 粒径と 無敷設時の污染物質排出量の関係を示したものであ る。図から吸着は川砂や東金産山砂にはあまり作用 せず，排出量を見ても川砂の場合，関東ロームの 3 倍〜 4 倍, 東金産山砂においても 1.5 倍から 3 倍位 の格差があることがわかる。この結果から, 粒径が 小さければ小さくなるほどその吸着力は強くなる。 以上のことから，污染物質の排出には載荷重よりも， 対象となる試料土に起因する傾向が強いことがわか った。

図-10, 図-11 は, 各試料土別に見た, 全排水 量と全污染物質排出量との関係を示した物であり, また表 -1 , 表 -2 , 表- 3 はそれらの全排水量と

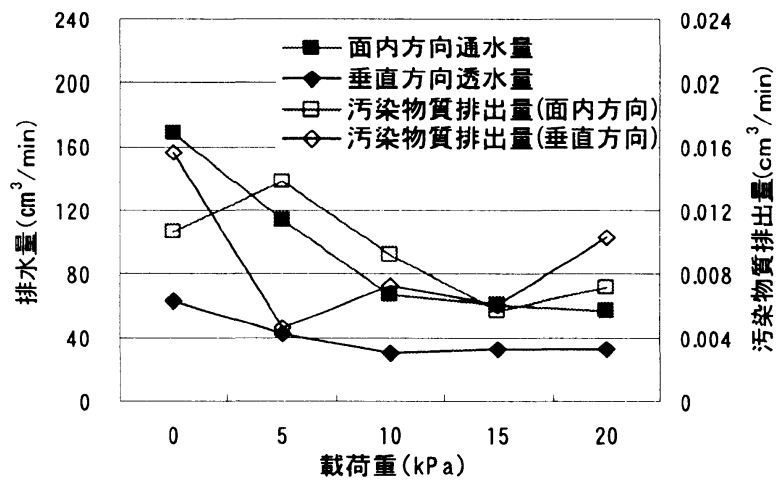

図－5 関東ロームにおける排水・排出量と 載荷重に関する関係（中央 3 枚）

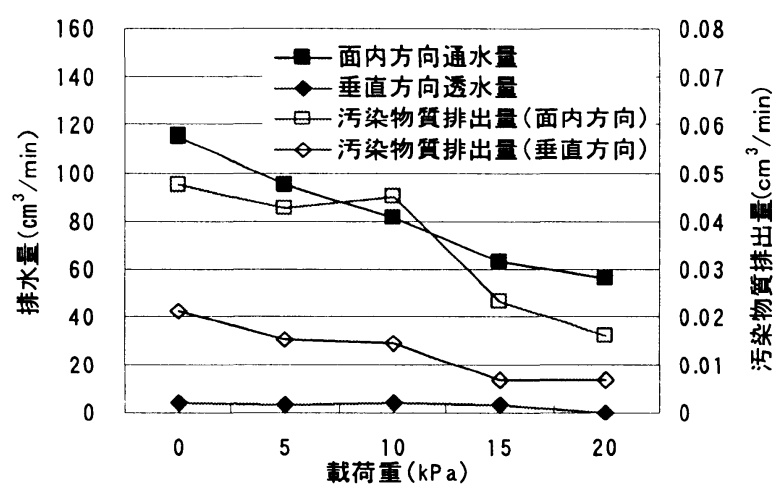

図-6 東金産山砂における排水・排出量と 載荷重に関する関係（分割 3 枚）

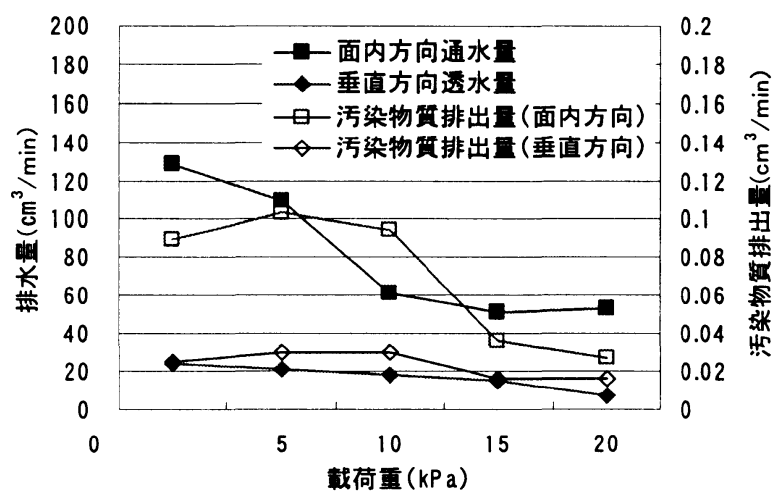

図-7 川砂における排水・排出量と 載荷重に関する関係（分割 3 枚）

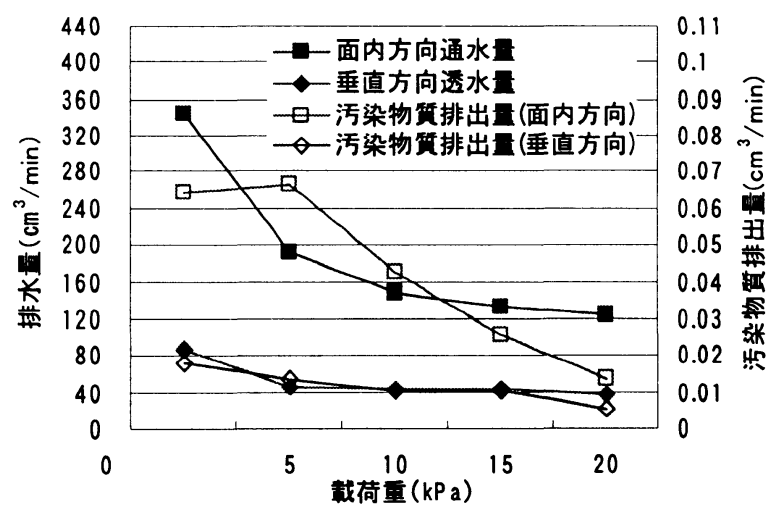

図-8 関東ロームにおける排水・排出量と 載荷重に関する関係（分割 3 枚） 


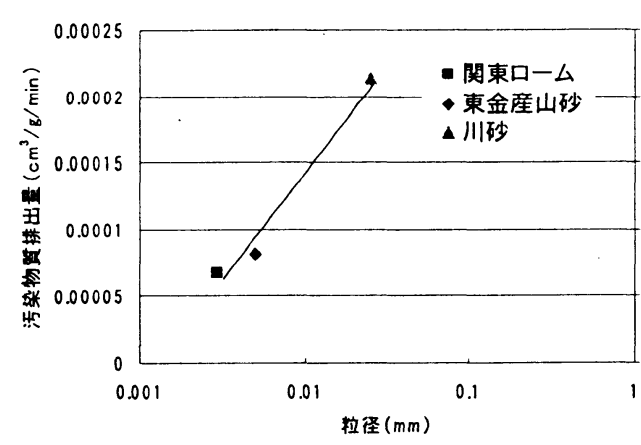

図-9 排出量と粒径の関係

表一 1 無敷設条件における排水・排出量

\begin{tabular}{|c|c|c|}
\hline 試料土 & 排水亶 $\left(\mathrm{cm}^{3} / \mathrm{min}\right)$ & 污染物質排出量 $\left(\mathrm{cm}^{3} / \mathrm{min}\right)$ \\
\hline 山砂 & 155.93 & 0.71 \\
\hline 川砂 & 402.87 & 1.91 \\
\hline 関東口ーム & 155.86 & 0.41 \\
\hline
\end{tabular}

表 -2 中央 3 枚敷設条件における排水 - 排出量

\begin{tabular}{|c|c|c|}
\hline 試料土 & 排水醍 $\left(\mathrm{cm}^{3} / \mathrm{min}\right)$ & 污染物篗排出量 $\left(\mathrm{cm}^{3} / \mathrm{min}\right)$ \\
\hline 山砂 面内方向 & 472.16 & 0.13 \\
\hline 山砂 垂直方向 & 25.05 & 0.13 \\
\hline 川砂 面内方向 & 884.14 & 0.21 \\
\hline 川砂 垂直方向 & 240.03 & 0.19 \\
\hline 関東口ーム 面内方向 & 467.80 & 0.05 \\
\hline 関東口一ム 重直方向 & 201.78 & 0.04 \\
\hline
\end{tabular}

表 -3 分割 3 枚敷設条件における排水・排出量

\begin{tabular}{|c|c|c|}
\hline 試料土 & 排水畺 $\left(\mathrm{cm}^{3} / \mathrm{min}\right)$ & 污染物筫排出量 $\left(\mathrm{cm}^{3} / \mathrm{min}\right)$ \\
\hline 山砂 面内方向 & 411.01 & 0.18 \\
\hline 山砂 垂直方向 & 14.51 & 0.06 \\
\hline 川砂 面内方向 & 404.50 & 0.35 \\
\hline 川砂 垂直方向 & 85.24 & 0.12 \\
\hline 関東口-ム 面内方向 & 1118.43 & 0.24 \\
\hline 関東口ーム 垂直方向 & 76.98 & 0.04 \\
\hline
\end{tabular}

表 -4 透水係数

\begin{tabular}{|c|c|c|c|}
\hline 語料土 & 東金産山眇 & 関東口-ム & 川眇 \\
\hline 透水係 & $2.22 \times 10^{-3}$ & $4.94 \times 10^{-4}$ & $1.20 \times 10^{-2}$ \\
\hline
\end{tabular}

ドレーン材の除去量を敷設条件別に数値化したもの である。

まず，污染物質排出量で見ると，東金産山砂にお いて無敷設で $0.71 \mathrm{~cm}^{3} / \mathrm{min}$, 川砂において無敷設で $1.91 \mathrm{~cm}^{3} / \mathrm{min}$, 関東ロームにおいて無敷設で $0.41 \mathrm{~cm}^{3} / \mathrm{min}$ と, 全ての試料土において敷設してい ない条件の方が油の排出量は多かった。しかし，全 排水量は, 全条件中一番低く排水量と污染物質排出 量は比例関係ではないことを裏付ける結果となった。

これには，前述したように油による目詰まり・吸 着が考えられ， ジオテキスタイルに油膜のような物 を作り，排出されるはずであった油がそのまま，ド レーン材内部に吸着・残留し, 以後の排水・排出に

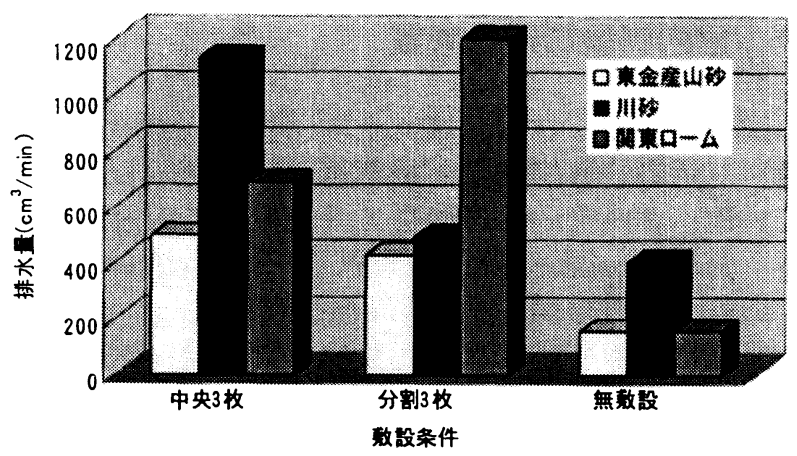

図-10 敷設条件別排水量の比較

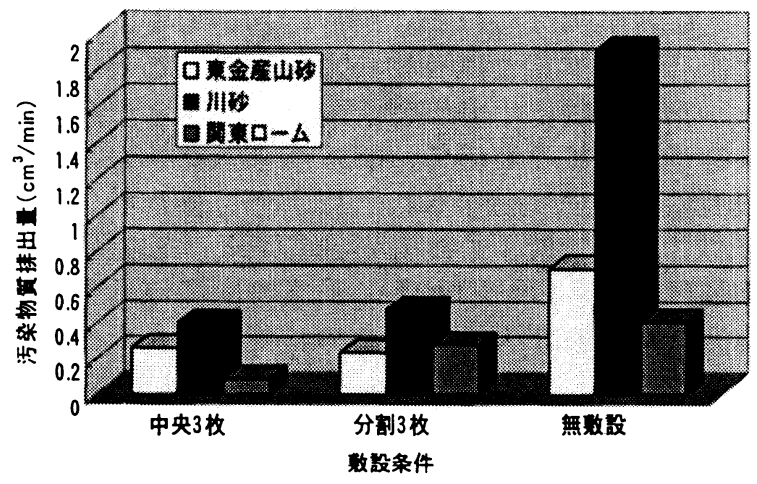

図-11 敷設条件別污染物質排出量の比較

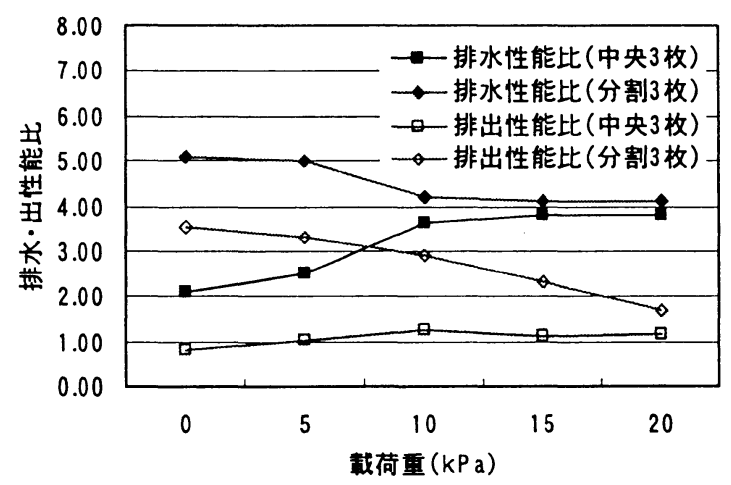

図-12 排水性能・排出性能比と載荷重の関係 （東金産山砂）

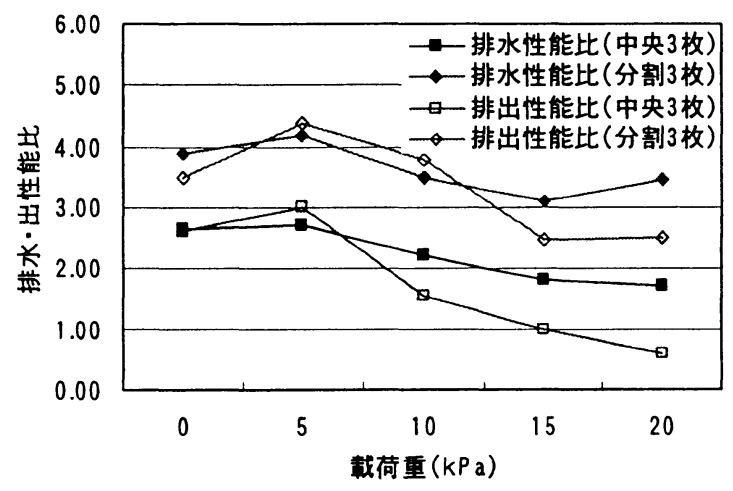

図-13 排水性能・排出性能比と載荷重の関係 (川砂) 
も影響を及ぼしたと考えられる。一方，無敷設の場 合ドレーン材のような吸着する物がないので, 水と 同様に油もそのまま浸透し，このような傾向を示し たと考えられる。また分割 3 枚敷設条件の通水量以 外は関東ロームの污染物質排出量が少なかった。こ のことからも, 粘性土特有の性質である吸着が作用 していることがわかる。

次に最も排水量が多い敷設条件で見てと，東金産 山砂において中央 3 枚で $497.21 \mathrm{~cm}^{3} / \mathrm{min}$ ，川砂にお いて中央 3 枚で $1124.17 \mathrm{~cm}^{3} / \mathrm{min}$, 関東ロームにおい て分割 3 枚で $1195.39 \mathrm{~cm}^{3} / \mathrm{min}$ と, 砂質土で中央 3 枚, 粘性土で分割 3 枚という結果になった。既往の研究 4)では，分割に 3 枚敷設するよりも中央 3 枚敷設し た方が，排水量は多くなる傾向とあった。これは， 中央 3 枚敷設の方が，土が目詰まりする䈯所が一箇 所になり，逆に 3 枚を分割して敷設すると，目詰ま りする箇所が 3 箇所に増加してしまい, ドレーン材 全体の透水係数が低下するという結果になった。今 回のようになった要因として，3枚重ねた 1 枚目に 油と土の強固な目詰まり現象を起こしたために, 残 り 2 枚の排水機能が発揮できなかったと考えられる が, 明確な原因解明は今後の研究課題とする。

今回, 排水性能試験結果として污染物質の排出に 関しては，あまり良い結果は得られなかったが，排 水量では中央 3 枚・分割 3 枚両条件とも, 無敷設の 状態と比較して全排水量は増加が確認できた。この ことから，ジオテキスタイルをドレーン材として敷 設することによって排水補強効果が期待できる。

表一 4 は今回の実験で使用する試料土別の透水係 数である。ここでは図示しないが載荷重を増加させ ると, 間隙比の減少などによりこの值よりも低い数 值となった。

図-12 図-14に各載荷重における面内方向通 水量と排水性能比・排出性能比の関係を示す。ここ で, 排水性能比 $\left(Q_{h} / Q_{v}\right)$ とは面内方向通水量 $Q_{v}$ と 垂直方向透水量 $\mathrm{Q}_{\mathrm{h}}$ の比で, 通水量の確保性を知る ためにこのような形で表した。同様に，油の排出量 を知るために排出性能比をという形で示す。排水性 能比同様に排出性能比 $\left(\mathrm{V}_{\mathrm{h}} / \mathrm{V}_{\mathrm{v}}\right)$ とは面内方向污染 物質排出量 $\mathrm{V}_{\mathrm{v}}$ と垂直方向污染物質排出量 $\mathrm{V}_{\mathrm{h}}$ の比率 のことをさす。これらの図を見ると殆どの条件で載 荷重の増加に伴い面内方向通水量, 排水性能比, 排 出性能比は減少傾向を示している。面内方向通水量 へ与えるマイナス要因としては, 載荷重による間隙 の減少, すなわち透水係数 $k$ の低下による排水量の 減少, また透水係数 $k$ に依存する浸透流の低下, 目 詰まりによる排水量の低下などがあり，プラス要因 としてはドレーン材の排水能力と集排水効果の組み 合わせによる排水量の増加, 載荷重による圧密排水 の促進（間隙水圧の上昇），試料土別では粒径の大 きさにおける吸着性（油に対する粘性）による排出 量の違い, 透水係数 $k$ の違いなどの様々な要因で結 果的にこのような減少するという変化が生じたと考 えられる。今回の試験結果では, 排水性能比が載荷

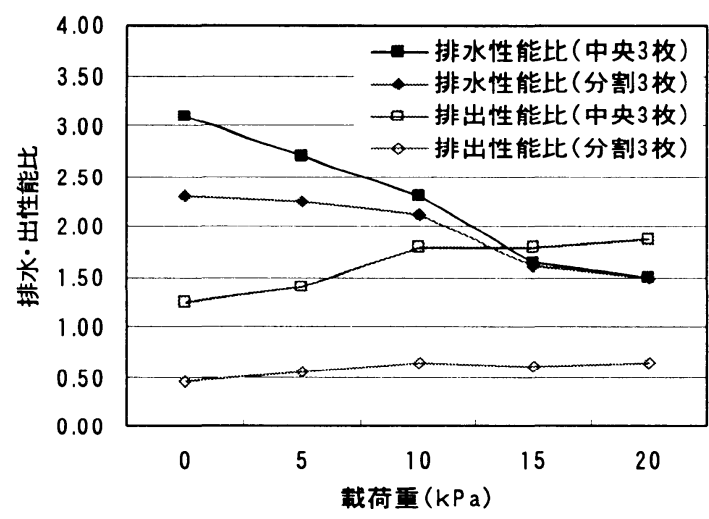

図-14 排水性能・排出性能比と載荷重の関係 (関東口ーム)

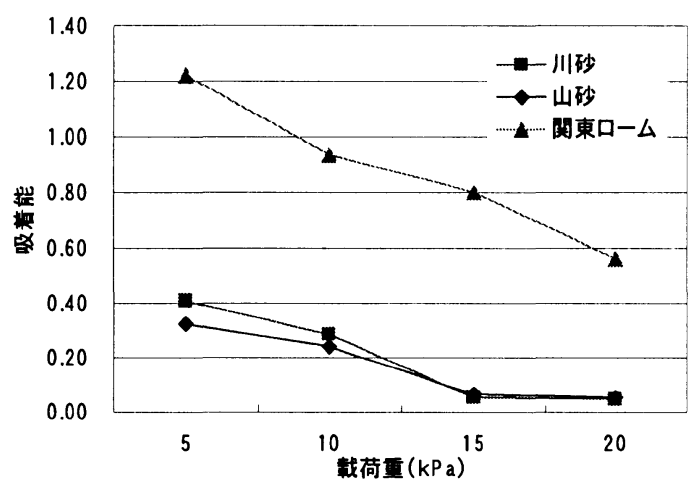

図一15 無敷設条件における 吸着能と載荷重の関係

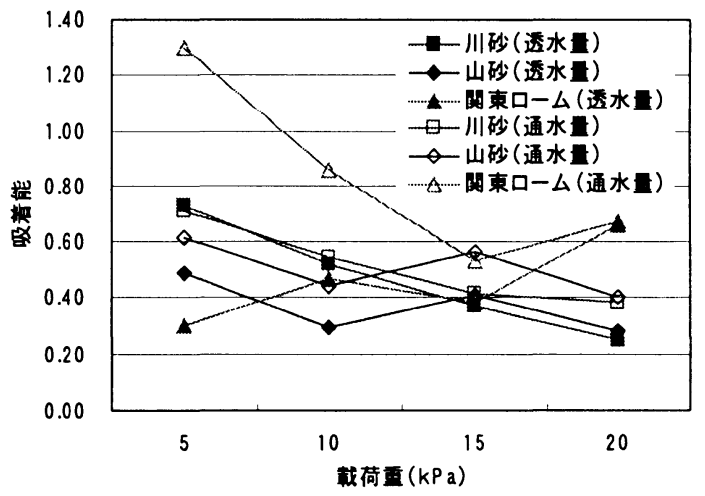

図-16 中央 3 枚敷設条件における 吸着能と載荷重の関係

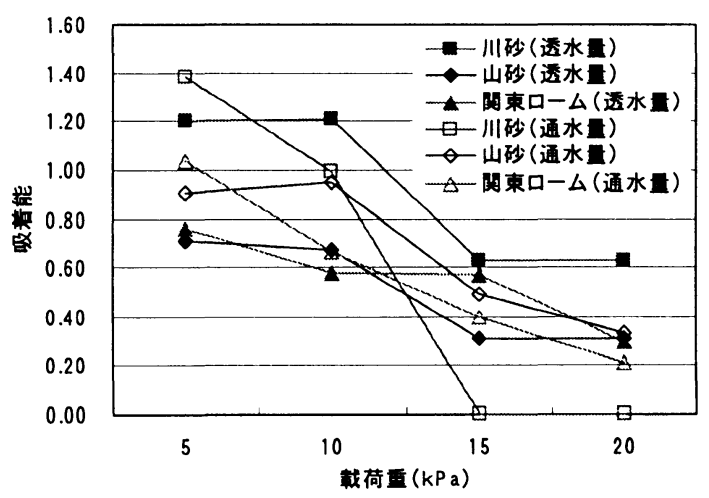

図-17 分割 3 枚敷設条件における 吸着能と載荷重の関係 
重を増やしても増加する傾向はなかった。これは, 既往の研究 ${ }^{4)}$ と異なって, 高い面内方向通水量を確 保できなかうたということである。むしろ，時間が 経過するにつれて油による目詰まりが激しくなって いくことを示す結果となった。

図-15 図-17 は各載荷重, 各土㙴における污 染物質排出量の吸着能の関係を示す。ここで, 吸着 能とは $5 \mathrm{kPa}, 10 \mathrm{kPa}, 15 \mathrm{kPa}, 20 \mathrm{kPa}$ での污染物質排 出量と無載荷状態での污染物質排出量との比率であ り，載荷をすることにより污染物質排出量が変化す るメカニズムを知るためにこのような形で表す。

図一15より, 川砂・東金産山砂に比べて関東口 一ムの吸着能が非常に高いことがわかる。これは㷙 述したように, 粘性土特有の吸着作用によるもので, 川砂・東金産山砂は $20 \mathrm{kPa}$ において 0.1 末満なの に対して関東ロームは 0.5 を超えているのがわかる。 図-16 からも中央 3 枚敷設条件においても同様の 傾向が得られたが, 吸着能は全体的に大きくなって いる。これは，ドレーン材の目詰まりにより浸透で きなくなったことで污染物質が蓄積してしまったた めと考えられる。しかし図一17 を見ると全体的に 減少傾向を示している。このことから分割に 3 枚敷 設したほうが污染物質は蓄積されないことがわかる。

また関東ロームの吸着能がすべての条件で載荷重 が $5 \mathrm{kPa}$ のと 1.0 を超えている。これは無載荷重 の場合よりも $5 \mathrm{kPa}$ のほうが污染物質排出量が多か ったことを示し, 載荷重を加えることでドレーン材 から吸着していた污染物質が押し出されたためと考 えられる。このことから污染物質排出量は多少なり とも載荷重の影響を受けるといえる。

\section{4. ガス吸引試験結果と考察}

本実験では, 排水・排出性能試験を行った後, 油 の残留濃度を調べるためにガス吸引試験を行った。 ガス成分の対象は, ベンゼンと石油ナフサである。 測定箇所は図 - 18 に示す通り 9 箇所の排水孔付近 に設定し，土中においてガス吸引試験を行った。試 験結果を表 -5 表 -7 に示す。中央 3 枚, 分割 3 枚の両試験条件ともべンゼンが殆ど検出されなかっ た。これは, ベンゼンは非常に空気中に消散しやす い物質でその融点は $5.5^{\circ} \mathrm{C}$ である。水に溶解して流 出したのではと考えたのだが, ベンゼンは水には溶 解しにくい物質でその密度は水よりも低い。

一方, 石油ナフサの沸点は $30^{\circ} \mathrm{C} \sim 120^{\circ} \mathrm{C}$ でこちら

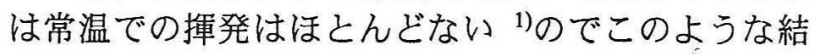
果になったと思わ㧈る。表一 5 〜表一 7 に示すよう に，敷設条件別に見てみると，東金産山砂，川砂両 条件においてドレーン材付近の濃度が高いのがわか る。川砂, 東金産山砂の中央 3 枚の上部 3 箅所 (図 -13 中の $1 ， 2,3$ の測定箇所）においては高い浄 化が確認され，ジオテキスタイルの集水効果によっ て油分が集められたことを意味する。しかし, 関東
ロームにおいては吸着性が高いために平均的な濃度 となっている。

前述したが敷設条件別の排水量・排出量の検討を 行ったが, 吸引試験と照らし合わせてみるとその結 果は, 川砂・東金産山砂においては排水量が高くな ればなるほど浄化効果が高くなることが確認された。

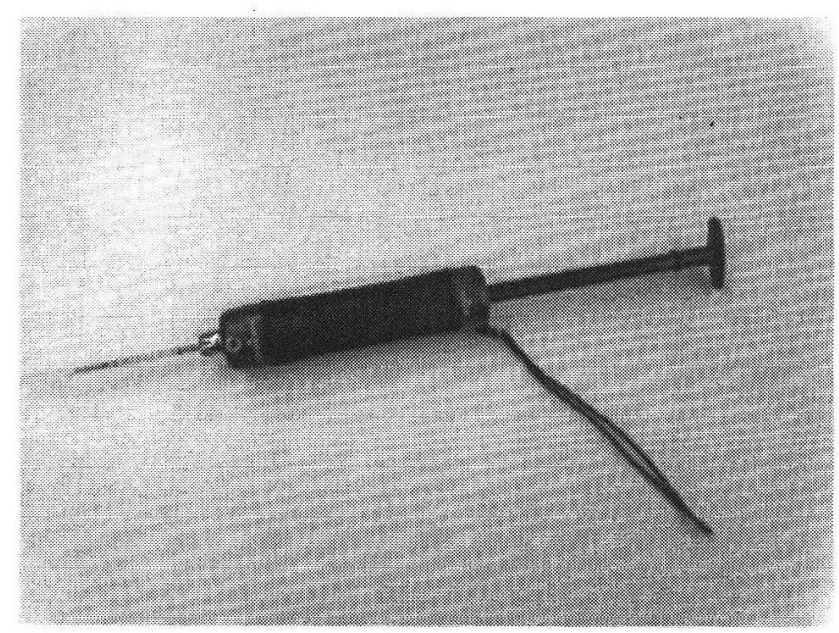

写真 -3 ガス吸引試験機

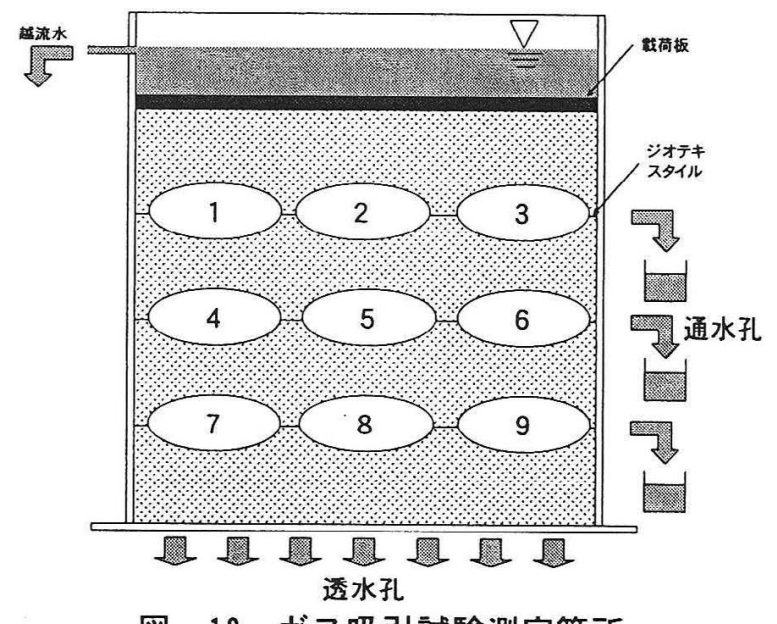

図-18 ガス吸引試験測定箇所

表 -5 東金産山砂におけるガス吸引試験結果

\begin{tabular}{|c||c|c|c|c|}
\hline \multicolumn{1}{|c|}{$\begin{array}{c}\text { 定 } \\
\text { 菌 }\end{array}$} & \multicolumn{2}{|c|}{ 中央3枚 } & \multicolumn{2}{c|}{ 分割3枚 } \\
\cline { 2 - 5 } & ベンゼン(ppm) & 石油ナフサ(mg/) & ベンゼン(ppm) & 石油ナフサ(mg/1) \\
\hline \hline 1 & 0 & 0.5 & 0 & 2.1 \\
\hline 2 & 0 & 0.8 & 0.1 & 1.8 \\
\hline 3 & 0 & 0.8 & 0 & 2 \\
\hline 4 & 0 & 1.2 & 0 & 1.3 \\
\hline 5 & 0.1 & 1 & 0.1 & 1.4 \\
\hline 6 & 0 & 0.9 & 0 & 1.6 \\
\hline 7 & 0 & 0.6 & 0 & 1.5 \\
\hline 8 & 0 & 0.8 & 0.1 & 2 \\
\hline 9 & 0 & 0.6 & 0 & 2.1 \\
\hline
\end{tabular}


表ー6 川砂におけるガス吸引試験結果

\begin{tabular}{|c||c|c|c|c|}
\hline \multicolumn{1}{|c||}{$\begin{array}{c}\text { 測 } \\
\text { 定 }\end{array}$} & \multicolumn{2}{|c|}{ 中央3枚 } & \multicolumn{2}{c|}{ 分割3枚 } \\
\cline { 2 - 5 } & ベンゼン(ppm) & 石油ナフサ(mg/) & ベンゼン(ppm) & 石油ナフサ(m8/) \\
\hline \hline 1 & 0 & 0.2 & 0 & 0.5 \\
\hline 2 & 0 & 0.7 & 0 & 0.8 \\
\hline 3 & 0 & 0.1 & 0 & 0.8 \\
\hline 4 & 0 & 0.2 & 0 & 1.2 \\
\hline 5 & 0 & 1.3 & 0.1 & 1 \\
\hline 6 & 0 & 1.8 & 0 & 0.9 \\
\hline 7 & 0 & 1.2 & 0 & 0.6 \\
\hline 8 & 0 & 1.4 & 0 & 0.8 \\
\hline 9 & 0 & 1.3 & 0 & 0.6 \\
\hline
\end{tabular}

\section{5. 結論}

以上の結果より今回得られた知見を以下にまとめ る。

（1）荷重を段階的に増加させることにより，排水 量は低下していく。これは, 関東ロームにおいて 顕著に見られ，透水係数・排水断面積の減少が主 な原因である。

（2）試料土への油の吸着には, 試料土の粒径に依 存する。粒径が小さくなるにつれて, 土粒子との 吸着は強くなる。

（3）化学的作用によるジオテキスタイルの目詰ま りは顕著に影響が出る。排水材の透水係数が $70 \%$ 位まで減少する場合もあるので, 今後検討が 必要である。

（4） 3 種類の土壌で試験を行ったが, 川砂，東金 産山砂において石油ナフサの隇少がみられたので, 土壤浄化の可能性を見出すことができたと言える。
表ー7 関東ロームにおけるガス吸引試験結果

\begin{tabular}{|c|c|c|c|c|}
\hline \multirow{2}{*}{$\begin{array}{l}\text { 涀 } \\
\text { 定 } \\
\text { 笛兽 } \\
\end{array}$} & \multicolumn{2}{|c|}{ 中央3枚 } & \multicolumn{2}{|c|}{ 分割3 枚 } \\
\hline & ベンゼン(ppm) & 石油ナフサ(mg/) & ベンゼン(ppm) & 石油ナフサ $(\mathrm{mg} /)$ \\
\hline 1 & 0 & 1.2 & 0 & 1.6 \\
\hline 2 & 0 & 1 & 0 & 1.7 \\
\hline 3 & 0 & 1.1 & 0 & 1.9 \\
\hline 4 & 0 & 2 & 0 & 1.7 \\
\hline 5 & 0 & 1.3 & 0 & 1.9 \\
\hline 6 & 0 & 1.5 & 0 & 1.7 \\
\hline 7 & 0 & 1.3 & 0 & 2 \\
\hline 8 & 0 & 1.5 & 0 & 1.8 \\
\hline 9 & 0 & 1.3 & 0 & 2 \\
\hline
\end{tabular}

\section{参考文献}

1)平田健正監修：土壌污染の対策と実務，（社）土 㙥環境センター, 2001

2)竹内均監修：地球環境調査計測事典, （株）フ ジ・テクノシステム, 2002

3）日本地盤環境浄化推進協議会編 : 土壌 - 地下水污 染の実態とその対策，（株）オーム社，2000

4) 椛澤竜生 : 地盤内におけるジオシンセティックス 水平ドレーン材の通水・透水特性, 日本大学修士 論文, 2001

\section{謝辞}

本研究を進めるにあたり, 元本学学生の増田貴之 氏の協力を得たことを記し，ここに感謝の意を示し ます。

\section{6. 今後の課題}

本研究では污染土壌で構築された盛土や擁壁など の地盤構造物を対象に室内モデル土槽試験機を作成 しジオテキスタイルを水平ドレーン材として適用し たときの面内方向通水性と垂直方向透水性の相互作 用または相関性について調べ, 土とジオテキスタイ ル複合体としての净化作用について調べたが, 試験 装置や解析にはまだ改良すべき余地があり，以下に 今後の課題を示す。

（1）試験土槽を改良してドレーン材の敷設条件を 検討し，より効率的な敷設条件を見出す。

（2）目詰まりをしない排水材を使用する。

（3）分散剤などを用いて污染物質の土㙥への吸着 をなくす。

（4）目詰まりによる透水係数の低減率を求め，そ れを条件に FEM 解析を行う。 


\title{
A Fundamental Study on Embankment Soil Remediation Using Geotextile
}

\author{
By Yuta KONNO, Kunio MINEGISHI and Katsuhiko MAKIUCHI
}

\begin{abstract}
There are a variety of soil remediation methods at present. In this study the effects of geotextile drain on soil remediation were investigated in the case of reuse of surplus soil for embankment. A laboratory model test was carried out using both cohesive and sand soils. It was found from the experiment that drainage and soil remediation effects were affected by overburden pressure, gradation of soil particles and placing condition of geotextile.
\end{abstract}

Key words: Geotextile, Drain, Soil remediation 